\title{
Combination therapy of atorvastatin and probucol on ischemic stroke in clinic
}

\author{
Tao Yan, Feng-Rui Yang, Lin Meng ${ }^{*}$ \\ From 2012 Sino-American Symposium on Clinical and Translational Medicine (SAS-CTM) \\ Shanghai, China. 27-29 June 2012
}

\section{Background}

Atorvastatin combined with probucol was considered in theory to be effects in treating ischemic stroke and preventing recurrent. However, the clinic data about it were very few, so we observed the effects of atorvastatin and probucol in combination in the patients with ischemic stroke.

\section{Methods}

90 inpatients of emerging ischemic stroke were randomly selected in this study. All patients in research group,diagnosed by CT and MRI inspection, which comply with the diagnostic criteria of cerebral infarction amended by the fourth national conference. All of them signed informed consent document. And this study had unambiguous exclusion criteria. The patients were divided into 3 groups, atorvastatin + probucol group $(\mathrm{n}=30)$, atorvastatin group $(\mathrm{n}=30)$, control group $(\mathrm{n}=30)$, observing for 6 months. Difference of every clinical index of these three groups was insignificant on admission. The blood lipids (including total cholesterol (TC), triglycerides (TG), low density lipoprotein cholesterol (LDL-C) and high-density lipoprotein cholesterol (HDL-C)), high-sensitivity C-reactive protein (hs-CRP) , pregnancy associated plasma protein (PAPP-A) level, intima-media thickness (IMT) and area of carotid intima of atherosclerotic plaque were tested before and after treatment respectively. The neurological deficit scores on the admission day and one month after admission were assessed, and the relationship between hs-CRP and the U.S. National Institutes of Health Stroke Scale (NIHSS)score and activities of daily living scale Barthel Index(BI) was analyzed.

\footnotetext{
* Correspondence: mdndy@126.com

Dept. Pharmacol. Tianjin Medical Univ. Tianjin 300070, China
}

\section{Results}

A significant drop of blood lipids $(\mathrm{P}<0.01), \operatorname{IMT}(\mathrm{P}<0.01)$, area of Carotid intima of atherosclerotic plaque $(\mathrm{P}<0.01)$, $\mathrm{PAPP}-\mathrm{A}(\mathrm{P}<0.01)$ and hs- $\mathrm{CRP}(\mathrm{P}<0.01)$ were observed in atorvastatin+ probucol group. All parameters were improved significantly comparing with atorvastatin alone. Neurological deficit scores of these two groups had significantly different after treatment $(\mathrm{P}<0.01)$. Combination therapy had better efficacy. The correlation analysis showed that seriousness of ischemic stroke on admission day and 1 month of treatment was associated with the hsCRP levels significantly.

\section{Conclusion}

Short-term use of atorvastatin combining with probucol could have a significant effect on ischemic stroke in clinic.

Published: 17 October 2012

doi:10.1186/1479-5876-10-S2-A61

Cite this article as: Yan et al:: Combination therapy of atorvastatin and probucol on ischemic stroke in clinic. Journal of Translational Medicine 2012 10(Suppl 2):A61.

Submit your next manuscript to BioMed Central and take full advantage of:

- Convenient online submission

- Thorough peer review

- No space constraints or color figure charges

- Immediate publication on acceptance

- Inclusion in PubMed, CAS, Scopus and Google Scholar

- Research which is freely available for redistribution 